\title{
矩形平面を持つ陸屋根の構造骨 組用風荷重
}

\section{DESIGN WIND LOADS FOR STRUCTURAL FRAMES OF RECTANGULAR FLAT ROOFS}

\author{
植松 康 - $* 1$ 茂木 剛 - $* 2$ \\ 上田 宏 一 $* 3$ \\ キーワード \\ 陸屋根, 動的応答, 設計用風荷重, 風圧係数, ガス卜影響係数
}

Keywords:

Flat roof, Dynamic response, Design wind load, Pressure coefficient, Gust effect factor

\author{
Yasushi UEMATSU $-* 1 \quad$ Tsuyoshi MOTEKI $-* 2$ \\ Hiroshi UEDA
}

The primary purpose of this study is to provide simple formulas for estimating the design wind loads for the structural frames of rectangular flat roofs considering the dynamic response to turbulent wind forces. Two types of structural systems are considered here; that is, (i) a series of simple beams arranged in parallel, and (ii) a structurally integrated type, which acts like an elastic plate, such as space truss. The characteristics of the first modal force are investigated, using a model of the pressure field on the roof. Based on the results, the gust effect factors for estimating the design wind loads are formulated as a function of the geometric and structural parameters of the roof and the turbulence intensity of approach flow. The formulas are verified by comparing the results on the load effects predicted by the formulas with those computed by using the experimental results for the modal force. The results of this study will be used for updating the specifications of roof wind loads in the AIJ Recommendations for Loads on Buildings.

\section{1.はじめに}

本研究の目的は，矩形平面を持つ陸屋根（あるいは，それと同様 の構造特性を有する屋根）を対象として, 簡便な構造骨組用風荷重 算定式を提案することである。

現在, 日本建築学会・風荷重小委員会では, 建築物荷重指針 ${ }^{1}$ （以 下，「荷重指針」という）の改訂作業を行っている。現行指針では, 「6.4 構造骨組用屋根風荷重」に屋根骨組設計用の風荷重算定式が 与えられているが，その対象は陸屋根を支持する構造梁に限定され ている。また, 算定式は, 1990 年頃までの限られた風洞寒験データ より風圧場のモデルを作成し，それを用いた一連の応答解析結果に 基づいて提案されたものであり，基本的な考え方はガスト影響係数

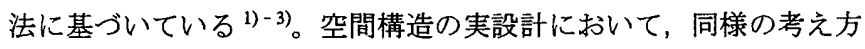
に基づき，風圧係数は風洞実験によって求め，ガスト影響係数を荷 重指針に基づいて設定している場合もある。

1993 年の荷重指針改訂以降, 屋根風荷重に関する研究がいくつか 為された。例えば, 上田ら ${ }^{4)}$-7) は陸屋根に作用する風圧の性状を詳 細に調べ，そのモデル化を行った。また，構造梁に作用する曲げモ 一メントやせん断力等の荷重効果に着目し, 気流のガストファクタ 一の 2 乗を基本としたガスト影響係数算定方法を提案した。一方, Uematsu et al. ${ }^{8-10}$ は, 屋根の風応答においては 1 次モード成分が支配 的であることに注目し，1 次一般化風力に関する一連の風洞寒験結 果に基づき,ガスト影響係数の簡便な評価式を提案した。そこでは， 構造梁だけでなく, 立体トラスのように屋根全体が一体となって挙 動するような構造形式も対象としている。

\footnotetext{
*1 東北大学末来科学技術共同研究センター 教授·工博 (广980-8579 仙台市青葉区荒巻字青葉10)

*2 侏)佐藤総合計画 修士 (工学)

(研究当時：東北大学大学院工学研究科都市. 建築学専攻 大学院生)

*3 千葉工業大学工学部建築学科 助教授・工博
}

本研究では, 以上の研究成果を踏まえ, 新たな調查や系統的解析 を行うことによって, 矩形平面を持つ陸屋根の構造骨組用風荷重に ついて考察する。なお，本報告は，荷重指針改訂のための基礎デー タを提供するために行った作業の結果をまとめたものである。

\section{2. 対象とする屋根構造}

本研究では，剛な構造物の上に架けられた屋根を対象とする。そ のような屋根の構造形式としては, 単純梁を並べた「梁型」と立体 トラスのような「構造一体型」(周辺単純支持の平板で近似)の 2 種 類が想定される。本研究で使用する記号は図 1 に示すように定義す る。「梁型」の場合, 梁の位置 $y$ によって最大荷重効果を与える風向 が異なり, 端部 $(0 \leq y / H \leq 1.5)$ では風向 $\mathrm{W} 1$, 中央部 $(1.5 \leq y / H \leq$ $B / H-1.5)$ では風向W2 である ${ }^{8)}$ 。一方, 「構造一体型」の場合, 風 向が長辺に直角な場合に荷重効果は最大となる9。

筆者らは，解析モデルの設定に先立ち，既存の空間構造の構造特 性について文献調查と設計者へのアンケート調查を行った。図 2 は 1 次モードに対する固有振動数 $f_{1}$ (鉄骨造のみ)および減衰定数 (臨 界減衰比） ら の実測值をスパンに対してプロットしたものである (一部，文献 11)より引用)。図2(a)中の実線および破線は，「梁型」 および「構造一体型」（ただし，正方形平面）に対して，自重による 最大撓み $\delta_{\max }$ がスパンの $1 / 300$ となるように屋根の曲げ剛性を設定 したときの結果であり，実測值の下限に概ね相当している。また，

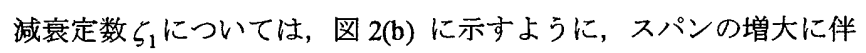
って增大する傾向を示す。鉄骨骨組の場合，風による動的応答が設

*1 Prof., New Industry Creation Hatchery Center, Tohoku Univ., Dr. Eng.

*2 AXS Satow INC., M. Eng.

(Formerly Graduate Student, Tohoku University)

*3 Assoc. Prof., Dept. of Architecture, Chiba Institute of Technology, Dr. Eng. 


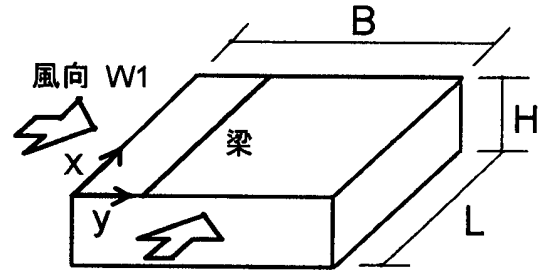

風向 W2

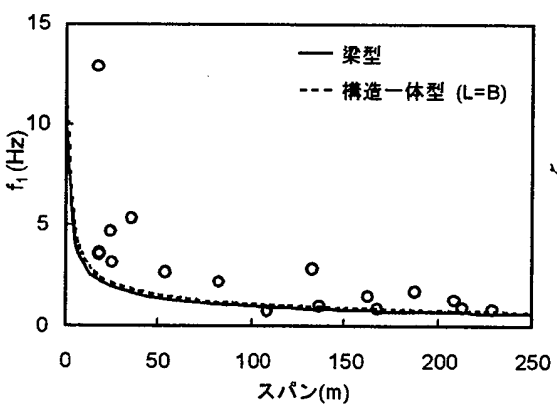

(a) 1次固有振動数

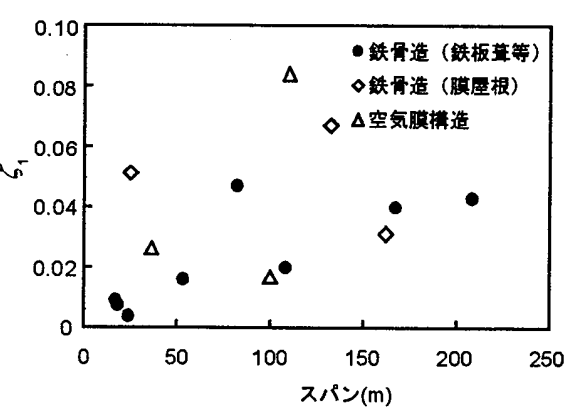

(b) 減衰定数

図 1 記号の定義

図 2 実測結果による既存の空間構造の 1 次固有振動数 $f_{1}$ と減衰定数 $\zeta_{1}$

計上重要となるスパン $50 \sim 60 \mathrm{~m}$ 以上の屋根に着目すると，ほぼ $\zeta_{1}>0.02$ となっていることが注目される。そこで, 本研究では，屋 根 (梁)の曲げ凮性は $\delta_{\text {max }}$ がスパン(「構造一体型」の場合, BとL のうち短い方)の $1 / 300$ となるように，また， $\zeta_{1}=0.02$ と設定する。

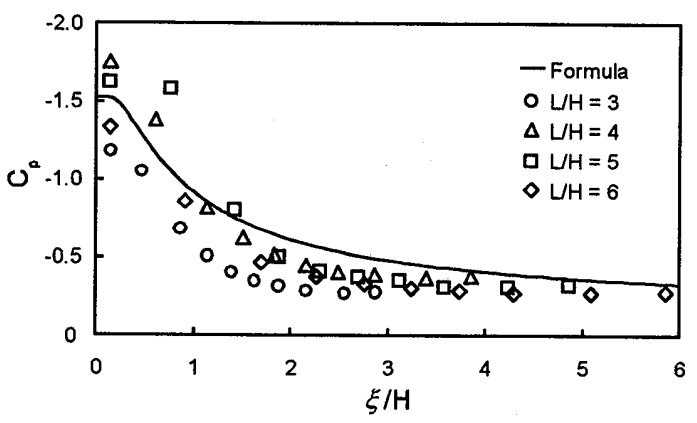

図 3 平均風圧係数 $C_{p}$ の $\xi$ 方向分布

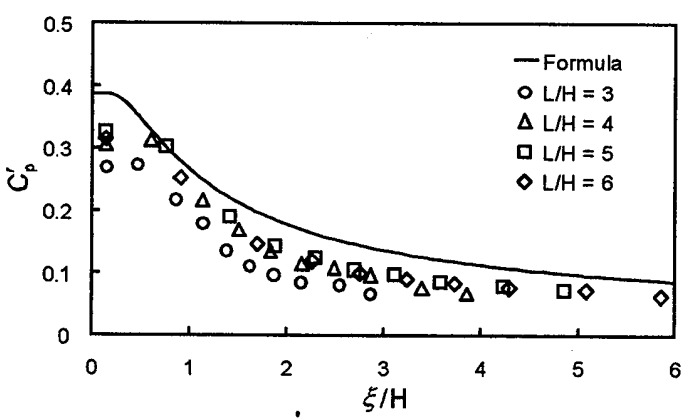

図 $4 \mathrm{RMS}$ 変動風圧係数 $C_{p}{ }^{\prime}$ の $\xi$ 方向分布

\section{3. 風圧場のモデル}

1 壁面に正対する風向を想定し，風方向および風直交方向の座標

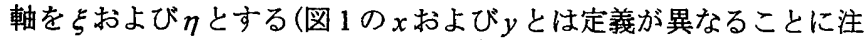
意)。ここでは, 主として上田ら ${ }^{4)}$ - クによる一連の風洞実験結果に 基づき，屋根面上の風圧力の特性をモデル化する。

平均風圧保数 $C_{p}$ および $\mathrm{RMS}$ 変動風圧係数 $C_{p}{ }^{\prime}$ (いずれも, 屋根 高さ(基隻高さ) $H$ での速度圧 $q_{H}$ で定義)の分布は， $\eta$ 方向の変化が 小さいため，近似的に次式で表すことができる。

$$
\begin{gathered}
C_{p}(\xi), C_{p}{ }^{\prime}(\xi)=\alpha+\beta \exp \left(-\frac{\gamma}{\xi / H}\right) \\
\alpha=a_{0} I_{u H}{ }^{a_{1}}, \beta=b_{0} I_{u H}^{b_{1}}, \quad \gamma=c_{0} I_{u H}{ }^{c_{1}}
\end{gathered}
$$

ここに, $I_{u H}$ は高さ $H$ における気流の乱れ強さであり, 定数 $a_{0}, a_{1}$, $b_{0}, b_{1}, c_{0}, c_{1}$ は以下の通りである。

$C_{p}: a_{0}=-0.36, a_{1}=0.50, b_{0}=0.47, b_{1}=0.37, c_{0}=4.2, c_{1}=-0.57$

$C_{p}{ }^{\prime}: a_{0}=0.0076, a_{1}=1.36, b_{0}=-0.01, b_{1}=1.24, c_{0}=24, c_{1}=-1.07$ 図3 と図 4 に上式(実線) とUematsu et al. $\left.{ }^{12}\right)$ による実験結果 $(O, \triangle$ 等) との比較を示す。いずれも同様の傾向を示すが，值はやや異なって いる。この違いは実験で用いた気流での乱れのスケール $L_{u x}$ の違い によるものと考えられる $\left(L_{u x} / H\right.$ の值は, 上田ら 6.8〜10 に対し, Uematsu et al. 1.9〜2.8)。但し, ガスト影響係数の評価には, $C_{p}{ }^{\prime} や$ $C_{p}$ の值そのものではなく, 両者の比が重要であり, この比はいずれ の実験でもほぼ同じであるので, ここでは(1)式を用いることとした。 変動風圧のパワースペクトル密度 $S_{p}(f)$ は, 気流の乱れに起因す る成分 $S_{t}(f)$ と前縁での流れの剥離に起因する成分 $S_{v}(f)$ の線形和 として次のように表せる。

$$
\begin{gathered}
S_{p}(f)=\kappa \cdot \lambda|\chi(f)|^{2} S_{t}(f)+(1-\kappa) S_{v}(f) \\
\frac{f S_{t}(f)}{\sigma_{p}^{2}}=\frac{4 f L_{u x}}{U_{H}}\left[1+70.8\left(\frac{f L_{u x}}{U_{H}}\right)^{2}\right]^{-5 / 6} \\
\frac{f S_{v}(f)}{\sigma_{p}^{2}}=\frac{3.6 f H}{U_{H}}\left[1+13\left(\frac{f H}{U_{H}}\right)^{2}\right]^{-1.5} \\
|\chi(f)|^{2}=\left[1+100\left(\frac{f H}{U_{H}}\right)^{2}\right]^{-0.7} \\
\lambda=\left.\left.\left|\frac{1}{\sigma_{p}^{2}} \int_{0}^{\infty} S_{t}(f)\right| \chi(f)\right|^{2} d f\right|^{-1}
\end{gathered}
$$

ここに, $U_{H}, L_{\imath x}=$ 高さ $H$ における風速, 乱れのスケール ; $\sigma_{p}=$ 変動風圧の標準偏差; $\kappa$ は $S_{t}(f)$ の寄与率であり次式で近似できる。

$$
\kappa=\left(\frac{0.8-\kappa_{3}}{9}\right)\left(\frac{\xi}{H}\right)^{2}+\left(\frac{2 \kappa_{3}-1.6}{3}\right)\left(\frac{\xi}{H}\right)+0.8 ; \text { for } 0 \leq \frac{\xi}{H} \leq 3
$$

$$
\kappa=\kappa_{3}+0.0442\left(\frac{\xi}{H}-3\right) ; \text { for } 3<\frac{\xi}{H}
$$


ただし， $\kappa_{3}$ は $\xi / H=3$ のときの值であり，

$$
\kappa_{3}=\exp \left(0.129 I_{u H} \frac{L_{u x}}{H}\right)-1
$$

ここで, $S_{p}(f)$ も方向には不変と仮定している。また，(3)式は上 田のモデルわを簡略化したものである。図 5 に実験結果 ( $○ 、 \triangle$ 等) とモデル式(実線)の比較を示す。図 6は，(2)，(3)式で表される $S_{p}(f)$ の $\xi / H$ による変化を示す。これより， $\boldsymbol{\xi} / H$ によって無次元パワー スペクトル密度の形状が大きく変化するのが分かる。図中の太い実 線は，現行の指針式を導くのに仮定した無次元パワースペクトル密

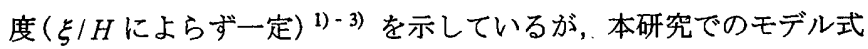
に比べて高振動数領域でのパワーがかなり高い。

屋根面上の 2 点 $\mathrm{P}_{1}\left(\xi_{1}, \eta_{1}\right)$ および $\mathrm{P}_{2}\left(\xi_{2}, \eta_{2}\right)$ における変動風圧の クロススペクトル密度 $S_{p 12}(f)$ は, 次式で近似できる。

$S_{p 12}(f)=\sqrt{S_{p 1}(f) S_{p 2}(f)} \exp \left(-k_{\xi} \frac{f|\Delta \xi|}{U_{H}}\right) \cos \frac{2 \pi f \Delta \xi}{U_{c}} \exp \left(-\kappa_{\eta} \frac{f|\Delta \eta|}{U_{H}}\right)$

ここに, $S_{p i}(f)=$ 点 $\mathrm{P}_{\mathrm{i}}$ における変動風圧のパワースペクトル密度 $(\mathrm{i}=$ $1,2) ; \Delta \xi=\xi_{2}-\xi_{1} ; \Delta \eta=\eta_{2}-\eta_{1} ; U_{c}\left(=\varphi U_{H}\right)$ は変動風圧の流下速度 である。(4)式中に含まれる 3 つの定数 $k_{\xi}, k_{\eta}, \varphi$ は， $\mathrm{P}_{1}$ および $\mathrm{P}_{2}$ の位置に依存するが，ここでは，上田わによる風洞実験結果に基 づき，平均的な值として $k_{\xi}=8, k_{\eta}=10, \varphi=0.6$ とおいた。なお， Marukawa et al. ${ }^{2)}$ は, 当時の限られたデータに基づき, $k_{\xi}=3, k_{\eta}=8$, $\varphi=0.55$ と仮定した。この場合, 設計荷重をやや過大評価する。

屋根の風応答は, 本来外圧と内圧の差で与えられる風力で決まる。 しかし，内圧性状は建物壁面に存在する隙間や開孔の大きさと位置 によって複雑に変化するため，外圧と内圧を併せて扱うことは，問 題を非常に複雑にする。本報告では現行指針での外圧と内圧のピー ク值の差をもって設計用風力とするという考えに則り，外圧のみに 着目する。

\section{1 次一般化変位に基づくガスト影響係数}

「構造一体型」の $j$ 次一般化風力係数 $C_{F j}(t)$ は次式で定義される。

$$
C_{F j}(t)=\int_{0}^{L} \int_{0}^{B} C_{p}(x, y ; t) \cdot \phi_{j}(x, y) d x d y / \int_{0}^{L} \int_{0}^{B} \phi_{j}^{2}(x, y) d x d y
$$

ここに, $C_{p}(x, y ; t)$ は点 $(x, y)$, 時刻 $t$ における風圧係数; $\phi_{j}(x, y)$ は モード形を表す。樑型」の場合, 本研究では, 簡単のため, 梁に
沿うライン上の風圧分布のみを考えるものとする。この場合、「ガス 卜影響係数はいくらか過大評価される(梁の荷重負担幅に依存)。

図 7 は, 風方向の梁(中央部, 風向 $\mathrm{W} 2$ ) について, 一般化風力係 数の平均値 $\bar{C}_{F j} お$ よび標準偏差 $C_{F j}$ をを示す(計算条件は $\left.L / H=4, I_{u H}=0.19\right)$ 。高次モード $(j \geq 2)$ の一般化風力保数は 1 次モ 一ドの值に対して有意な大きさ (1/3〜1/4 程度)になる。しかし, 固 有振動数は $j^{2}$ (従って, 剛性は $j^{4}$ )に比例するため, 変位や応力度と いった荷重効果に着目すると, 高次モードの影響は小さく，1 次モ 一ド成分が卓越するようになると言える。紙面の都合上結果は割愛 するが，風直交方向の梁および「構造一体型」に関してもほぼ同様 であった。従って，一般に陸屋根における最大荷重効果は，1 次一 般化変位に基づくガスト影響係数 $G_{f}$ で評価できると言える。すな わち, 設計荷重は近似的に平均風圧と $G_{f}$ の積で評価できると考え られる。そこで，以下においては 1 次モードのみに着目する。

不規則振動理論によれば，1 次一般化変位に基づくガス卜影響係 数は近似的に次式で表せる。

$$
G_{f}=1+g \cdot r_{F} \cdot R=1+g \cdot r_{F}\left(1+\frac{\pi}{4 \zeta_{1}} \frac{f_{1} S_{F 1}\left(f_{1}\right)}{\sigma_{F 1}^{2}}\right)^{1 / 2}
$$

ここに, $g$ はピークファクター; $S_{F 1}(f)$ および $\sigma_{F 1}$ は 1 次一般化風 カ $F_{1}(t)$ のパワースペクトル密度および標準偏差 ; $r_{F}$ は $C_{F j}(t)$ の標 準偏差と平均值の比 $C_{F 1}{ }^{\prime} /\left|\bar{C}_{F 1}\right|$ (以後, 一一般化風力係数比」と呼 ぶ)；R は共振応答倍率を表している。上式から明らかなように, $r_{F}$ と 1 次一般化風力の無次元パワースペクトル密度 $f S_{F 1}(f) / \sigma_{F 1}{ }^{2}$ が定 式化できれば， $G_{f}$ を容易に算定できる。

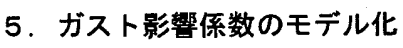 \\ 5. 1 一般化風力係数比}

「梁型」に関する結果の例を図 8 に示す。なお，風向W1 の場合， 梁の位置は $y / H=0.5$ とした（以下，基本的にはこの位置を仮定）。 また, 既往の風洞実験結果 ${ }^{8)}$ と比較するため, 乱れの強さ $I_{u H}$ は 0.10 および 0.19 とした。図より, 本解析結果は風洞実験結果に概ね一致 しているのが分かる。なお，境界条件の影響を調べるため, 本研究 での基本的な仮定としての「単純支持」のほか「固定支持」につい ても同様の計算を行った。その結果, 両者には大きな違いはなく, $r_{F}$ に及ぼす境界条件の影響は小さいことが明らかになった。図中の実 線および破線は, Uematsu et al. ${ }^{8)}$. 9)による奏験公式((7)式)であるが, 実験結果および本解析結果に概ね対応している。

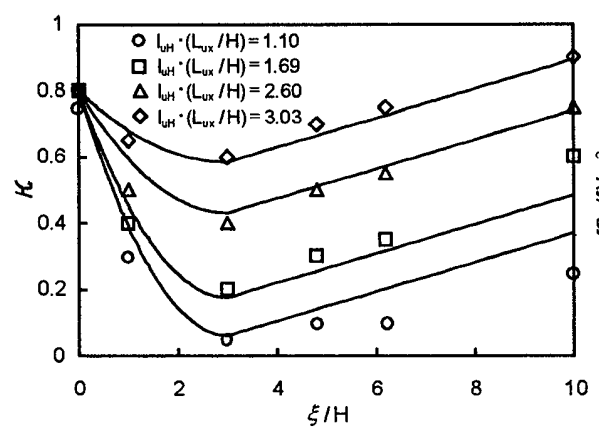

図5 寄与率 $\kappa$ $\boldsymbol{\xi} / H$ による変化

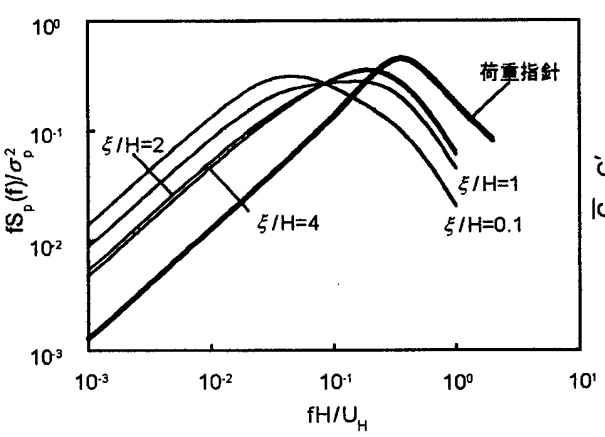

図6 変動風圧のパワースペクトル密度 $S_{p}(f)$

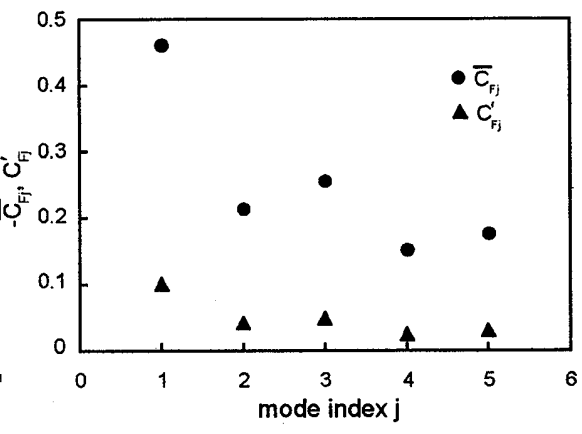

図7一般化風力の平均值と標準偏差 


$$
\begin{gathered}
r_{F}=L_{B} K_{I} \exp \left(-\gamma \frac{L}{H}\right) \\
L_{B}=l_{0}+l_{1}\left(\frac{\xi}{H}\right)^{2} \\
K_{I}=\kappa_{0}+\kappa_{1} I_{u H}{ }^{2}
\end{gathered}
$$

上式において $L / H$ がある限界值 $(L / H)_{\mathrm{cr}}$ より大きい場合, $L / H=(L / H)_{\mathrm{cr}}$ とする。上式中の係数は表 1 に示す通りである。風向 W1 の場合, $L / H>6$ での $r_{F}$ の変化は小さいと考えられるので, 安全側の設定と して $(L / H)_{\mathrm{cr}}=6$ とおいた。 $\gamma$ はいわる「規模効果」に関連している。 (4)式において $k_{\xi}<k_{\eta}$ にも拘らず, 風向 W2 に対する $\gamma$ の值の方が大 きいのは, 変動風圧の流下現象に起因していると考えられる。

上田 》は, 共振効果の無視できる剛な梁を対象とし, 曲げモーメ ントやせん断力の時刻歴応答に基づいてガスト影響係数 $G_{f b}$ を求め, $G_{f b}$ に及ぼす規模効果を検討した。図 9 は， $G_{f b}$ に及ぼす $L H$ の影響 について,(6), (7)式から計算される結果 ( $g=4, R=1$ と仮定) と上田 による実験公式の結果 $(O ， \triangle$ 等)を比較したものである。実験デー タのばらつきを考えれば，両者はよく対応していると言えよう。

表 $1 r_{F}$ の実験公式(7)に含まれる係数

\begin{tabular}{lllllll}
\hline 風向 & $\gamma$ & $(L / H)_{\mathrm{cr}}$ & $\kappa_{0}$ & $\kappa_{1}$ & $l_{0}$ & $l_{1}$ \\
\hline $\mathrm{W} 1$ & 0.10 & 6 & 0.15 & 5.0 & 0.95 & 0.3 \\
$\mathrm{~W} 2$ & 0.15 & 4 & 0.20 & 3.5 & 1.0 & 0 \\
\hline
\end{tabular}

次に「構造一体型」に関する結果の例を図 10 に示す。これは, 奥行きを $L / H=4$ に固定し, 幅を $B / H=2 \sim 8$ の範囲で変化させたも のである (図 1 の風向 W2 に相当)。解析結果と実験結果 ${ }^{9}$ を比較す ると， $B \geq L(B / H \geq 4)$ の場合両者はよく一致しているが， $B<L(B / H$ <4)では $B / H$ の減少に伴い両者の差が広がっている。これは，本解 析では風圧場の統計的特性が風直交方向には変化しないと仮定して いるのに対して，実際には側面からの流れの巻き込み等， 3 次元効 果が影響するためと考えられる。すなわち, 3 次元効果によって, $r_{F}$ 式の分母である平均風力 $\left|\bar{C}_{F 1}\right|$ が减少し, 一方分子である変動風力 $C_{F_{1}}{ }^{\prime}$ が增大することによる結果である(図 11 参照)。

図 10 中には次式で表される実験公式も併せて示している。

$$
\begin{gathered}
r_{F}=\left\{K_{I}+0.0039\left(\frac{L}{H}\right)^{2}\right\} \exp \left(-0.10 \frac{B}{H}\right) \\
K_{I}=0.09+3.8 I_{u H}^{2}
\end{gathered}
$$

ここで, $L / H<4$ のとき $L / H=4, B / H>6$ のとき $B / H=6$ とする。こ

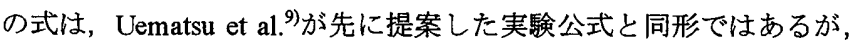
本解析結果を踏まえて係数をいくらか変更したものである。(8.a)式 を見ると， $L / H$ が増大すると $r_{F}$ も増大するという, 規模効果に矛盾 する結果となっているが，これは前述したように流れの3 次元性に 起因していると考えられる。現実問題としては, 風向が長辺に直角 の場合に最大の荷重効果が生じるので，(8)式は $B \geq L$ として適用す べきである。そのような条件下では，(8)式の結果は実験および本 解析の結果ともよく一致している。

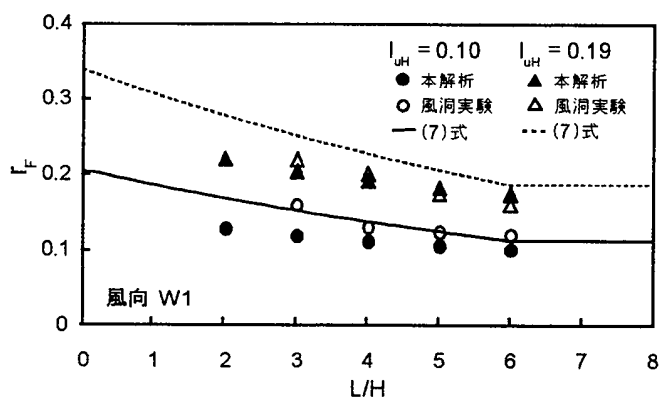

（a）風直交方向の梁(端部，風向 W1)

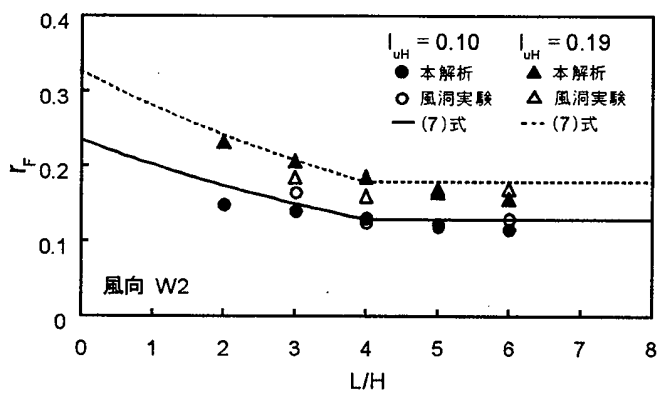

(b) 風方向の梁 (中央部, 風向 W2)

図 8 構造梁に対する $r_{F}$ と $L / H$ の関倸

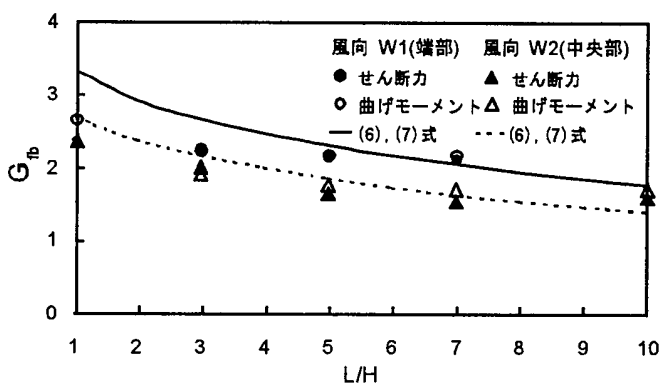

図 9 剛な構造梁のガスト影響係数に及ぼす規模効果

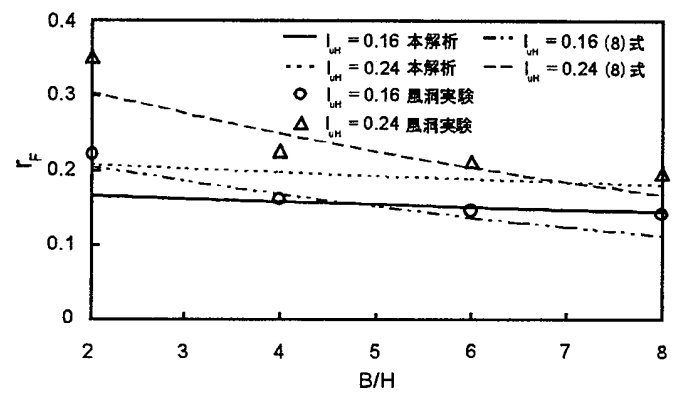

図 10 「構造一体型」に対する $r_{F}$ と $B / H$ の関係 $\left(I_{u H}=0.25, L / H=4\right)$

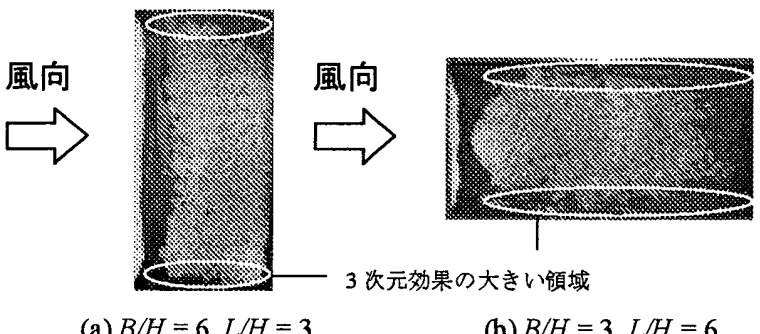

図 11 風砂法による屋根表面流孔の可視化 $(H=5 \mathrm{~cm})$ 


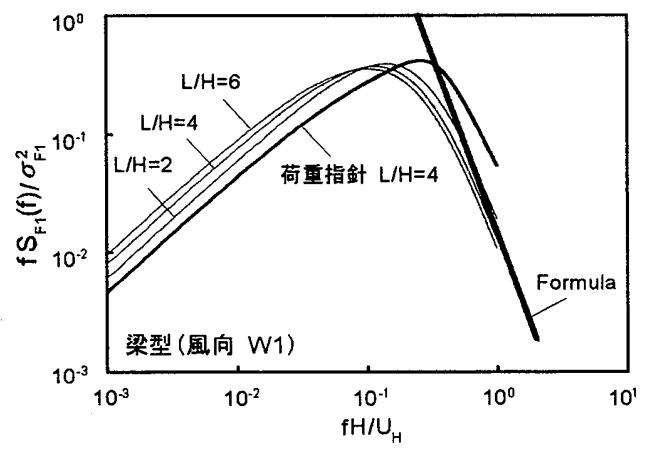

(a)風直交方向の梁 (端部，風向 W1)

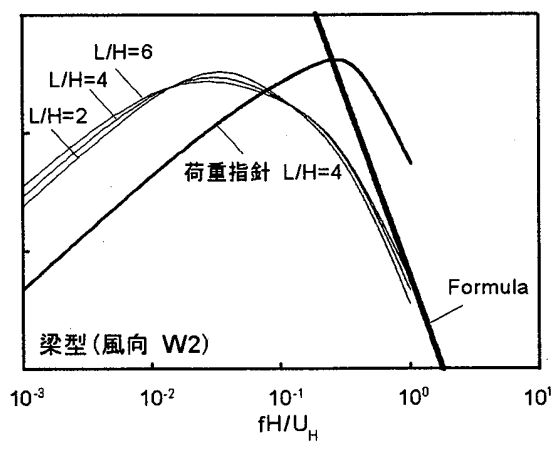

(b)風方向の梁 (中央部, 風向 W2)

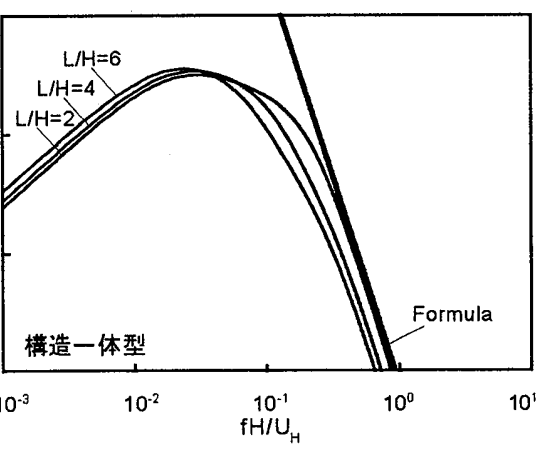

(c)「構造一体型」 $(B / H=L / H)$

図 121 次一般化風力の無次元パワースペクトル密度 $f S_{F 1}(f) / \sigma_{F 1}{ }^{2}$

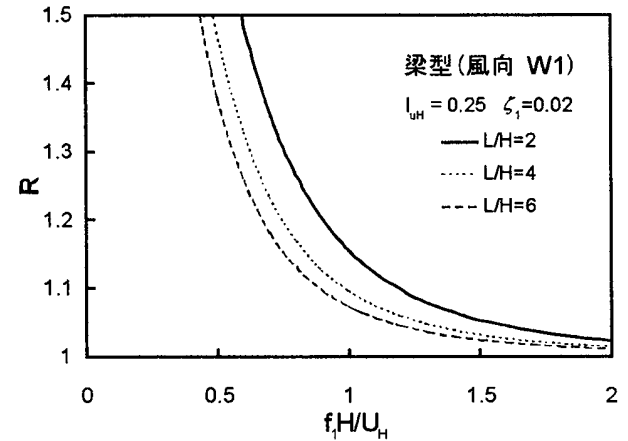

(a)風直交方向の梁 (端部，風向 W1)

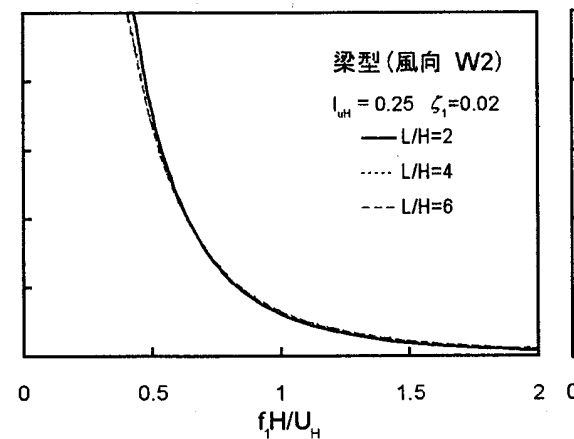

(b)風方向の梁 (中央部, 風向 W2)

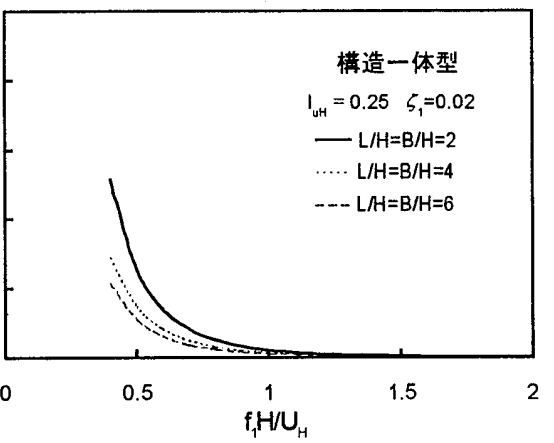

(c)「構造一体型」

図 13 共振応答倍率 $R$

\section{2 パワースペクトル密度}

「梁型」および「構造一体型」に対する 1 次一般化風力 $F_{1}(t)$ の無 次元パワースペクトル密度を図 12 に示す。「梁型」については, 現 行の指針式を得るのに仮定した変動風圧のクロススペクトル密度 ${ }^{1)}$ 一)を用いて計算した結果も併せて示してある。本解析結果と比べる と荷重指針の $f S_{F 1}(f) / \sigma_{F 1}$ は, 高振動数領域でのパワーが高い。こ

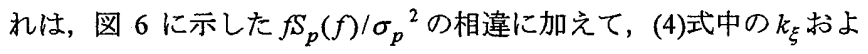
び $k_{\eta}$ の值を小さく仮定したためである。図 2 からも分かるように, 実際の構造物の無次元固有振動数 $f_{1} H / U_{H}$ は 0.7 程度より大きくな る (例えば, $H=30 \mathrm{~m}, U_{H}=40 \mathrm{~m} / \mathrm{s}$ を想定してみる)。そのような $f_{1} H / U_{H}$ に着目すると， $L H$ の影響は一般に小さい。また，図には示してい ないが, $I_{u H}$ が増大すると高振動数側にいくらかシフトする(同様の 性状は風洞実験でも観測されている $\left.{ }^{8)-109}\right)$ 。いま, $f H / U_{H}>0.7$ な る範囲に着目すると, $f S_{F 1}(f) / \sigma_{F 1}{ }^{2}$ は近似的に次式で表せる。

$$
\frac{f S_{F 1}(f)}{\sigma_{F 1}^{2}}=A\left(\frac{f H}{U_{H}}\right)^{-\beta}
$$

係数 $A$ および $\beta$ の值は構造形式や気流性状によって異なるが, 本研 究では表 2 のように設定した。図 12 中の太い実線は(9)式で与えら れる関係である。解析結果よりいくらか上側に設定されているのは, 荷重指針で想定している $I_{u H}$ の幅を考慮し, 全体をほぼ包絡するよ うに係数を設定したためである。

1 次一般化風力の無次元パワースペクトル密度を用いて共振応答 倍率 $R$ を計算した結果を図 13 に示す。一般に, $R$ の值は $f_{1} H / U_{H}$ の 増大に伴って減少し， $f_{1} H / U_{H}>1$ では概ね 1.1 以下になっており， この範囲では変動風力の共振効果が比較的小さいと言える。
表 $2 f S_{F 1}(f) / \sigma_{F 1}{ }^{2}$ の実験公式(9)に含まれる係数の值

\begin{tabular}{llll}
\hline 係数 & 梁型・風向 W1 & 梁型・風向 W2 & 構造一体型 \\
\hline$A$ & 0.015 & 0.006 & 0.001 \\
$\beta$ & 3.0 & 3.0 & 3.5 \\
\hline
\end{tabular}

\section{6. 風圧係数のモデル化}

ガスト影響係数の定式化に加え, 風圧係数 $C_{p}$ の $\xi$ 方向分布をそデ ル化することによって荷重算定方法を簡略化できる。本研究では図 14 に示すような階段状の分布でモデル化し, 各領域内で $C_{p}$ が一定 $\left(C_{p 1}\right.$ および $\left.C_{p 2}\right)$ とし, 空間平均した值とする。

領域 I 内の $C_{p}$ 分布は, 剥離せん断層の性状と強く関連するため, 乱れの強さ $I_{u H}$ の影響を強く受ける。一方, 領域 II 内の分布は, $I_{u H}$ の影響をあまり受けず，風上端からの距離とともに徐々に低下する 傾向を示す。従って, 空間平均して得られる $C_{p 2}$ に対する支配的な パラメータは $L / H$ と考えることができる。そこで, 風圧係数分布に 関する既往の風洞実験結果 4$)$, ク, 12)-15) より $C_{p 1}$ および $C_{p 2}$ を計算し, それぞれ， Iuおよび $L / H$ の関数としてプロットしたものが図 15 お よび図 16 である。実験データのばらつきは大きいが, $\left|C_{p 1}\right|$ は $I_{u H}$ の増大に伴って増大する。一方, $\left|C_{p 2}\right|$ は $L / H$ の増大に伴って堿少す る傾向を示す。図中の実線は次式で与えられる実験公式である。

$$
\begin{gathered}
-C_{p 1}=1.6-\exp \left(-6.0 I_{u H}\right) \\
-C_{p 2}=0.4+0.5 \exp \left(-0.3 \frac{L}{H}\right)
\end{gathered}
$$

但し，(10.a)式では実験データの範囲を考え， $I_{u H} \leq 0.3$ とする。 


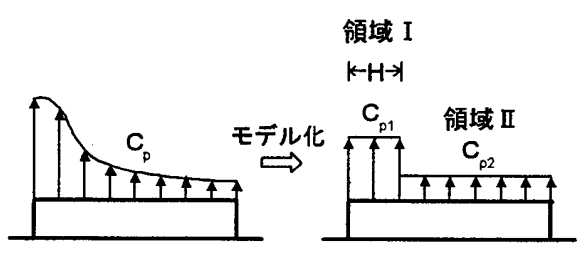

図 14 風圧保数分布のモデル化

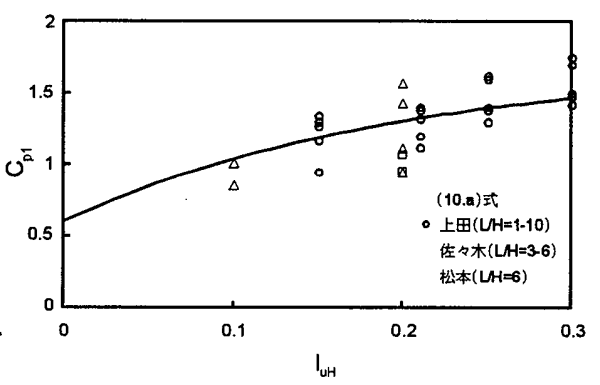

図 $15 C_{p 1}$ と $I_{u H}$ の関係

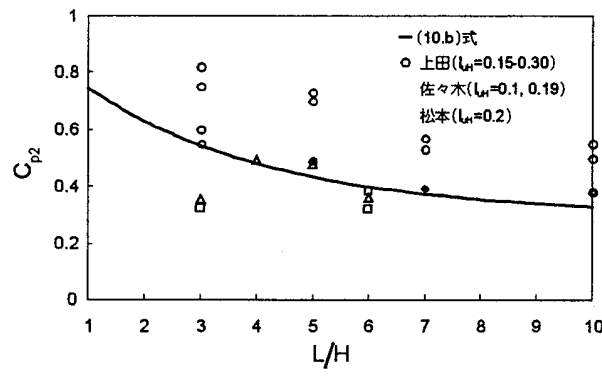

図 $16 C_{p 2}$ と $L / H$ の関係

\section{7. 何重算定式の妥当性}

上で得られたガスト影響係数と風圧係数分布のモデル式の妥当性 を確認するため，構造梁(単位幅)を対象として，モデル式から計算 される曲げモーメントの最大值 $M_{\max }{ }^{(1)}$ と 3 . に示した風圧場のモデ ルを使って計算される曲げモーメントの最大值 $M_{\max }{ }^{(2)}$ を比較した。 検討したケースは, $I_{u H}=0.1 \sim 0.3$ (3 種類),$L / H=2 \sim 6$ (5 種類), $f_{1} H / U_{H}=0.6 \sim 1.5$ (4 種類) の 60 ケースである。風向 W1 (端部)につい て, $M_{\max }{ }^{(1)}$ と $M_{\max }{ }^{(2)}$ の比 $R_{12}$ をヒストグラムで表した結果を図 17(a) に示す。全ケースに対する平均值 $\bar{R}_{12}$ および標準偏差 $\sigma_{R_{12}}$ は以下の ようであった。

風向 W1 (端部): $\bar{R}_{12}=1.01, \sigma_{R 12}=0.110$ (変動係数 0.109 )

風向 $\mathrm{W} 2$ (中央部) : $\bar{R}_{12}=1.03, \sigma_{R 12}=0.109$ (変動保数 0.105)

次に, $I_{u H}=0.15,0.25$ ( 2 種類),$L / H=2 \sim 6$ (5 種類), $f_{1} H / U_{H}=0.6$ $\sim 1.5$ (4 種類)の 40 ケースについて, $C_{p}$ 分布と $G_{f}$ に関する上田 ${ }^{8)} の$ 実験公式を用いて計算される結果 $M_{\max }{ }^{(3)}$ と $M_{\max }{ }^{(1)}$ との比較を行った。 図 17(b)は, 風向 W1 (端部)について, $M_{\max }^{(1)} と M_{\max }{ }^{(3)}$ の比 $R_{13}$ の七 ストグラムである。全ケースに対する平均值 $\bar{R}_{13}$ および標隻偏差 $\sigma_{R_{13}}$ は以下のようであった。

風向 W1 (端部)： $\bar{R}_{13}=1.00, \sigma_{R 13}=0.090$ (変動係数 0.090 )

風向 $\mathrm{W} 2$ (中央部) : $\bar{R}_{13}=1.04, \sigma_{R 13}=0.039$ (変動係数 0.037 ) これらの結果より, 本研究で提案したモデルは概ね妥当であると言 えよう。
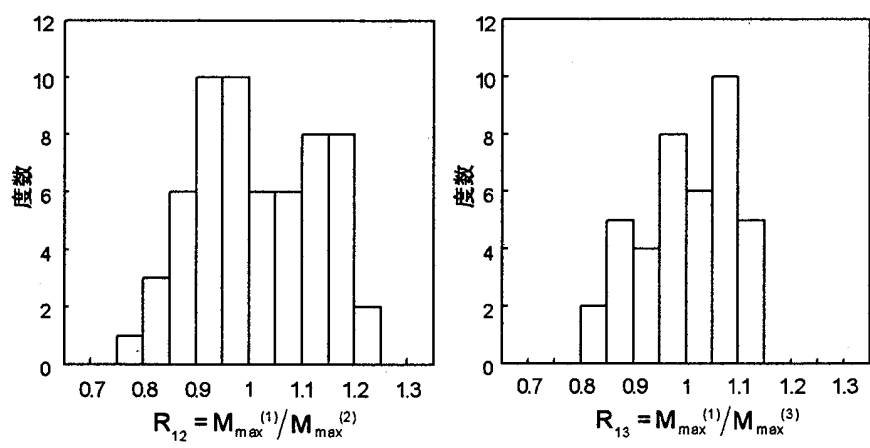

(a)風圧モデルから計算される結果との比較 (b)上田の実呀公式による結果との比較 図 17 最大曲げモーメントに対する結果の比較 : 風直交方向の梁 （端部，風向 W1）

\section{8.おわりに}

1993 年の荷重指針改訂により, 構造骨組用屋根風荷重の算定式が 導入され, 空間構造の耐風設計に寄与してきた。一方, 改訂以降も 算定式の簡略化と合理化, さらに適用範囲の拡大を図るため, 上田

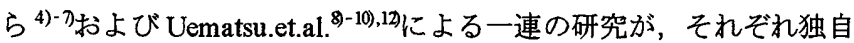
に進められてきた。今般, 荷重指針の再改訂作業の一環として，筆 者らは既往の研究成果を総合的に考察し，様々な観点から設計荷重 について検討した。本報告は，そのうちの矩形平面を持つ陸屋根の 構造骨組用風荷重に関する結果をまとめたものであり，荷重指針改 訂のバックデータを提供する。

本研究を進めるに当り, 日本建築学会・風荷重小委員会・応答 WG および屋根 SWG の委員各位より貴重なご意見を頂いた。ここ に記し，感謝の意を表する。

\section{参考文献}

1) 日本建築学会 : 建築物荷重指針・同解説，1993.6

2) H. Marukawa, Y. Uematsu, Y. Tamura, O. Nakamura and H. Ueda: Design wind load on a flat long-span roof, Proc. 4th East Asia-Pacific Conference on Structural Engineering and Construction, Vol. 3, pp. $1619-1624,1993.9$

3) Y. Tamura, H. Kawai, Y. Uematsu, H. Marukawa, K. Fujii, Y. Taniike: Wind load and wind-induced response estimations in the Recommendations for Loads on Buildings, AIJ 1993, Engineering Structures, Vol. 18, No. 6, pp. 399-411, 1996

4) 上田 宏, 田村幸雄, 藤井邦雄 : 陸屋根の平均風圧性状に対す る気流の乱れの影響 (陸屋根の風圧性状に関する研究: その 1), 日本建築学会構造系論文集，第 425 号，pp. 91-99, 1991

5) 上田 宏, 田村幸雄, 藤井邦雄 : 陸屋根の変動風圧性状に対す る気流の乱れの影響（陸屋根の風圧性状に関する研究：その 2)， 日本建築学会構造系論文集, 第 447 号, pp. 17-30, 1993

6) 上田 宏, 田村幸雄 : 陸屋根構造梁の等価設計用風圧係数, 日 本建築学会構造系論文集，第 464 号，pp. 59-69, 1994

7)上田 宏: 変動風圧による荷重効果を考慮した陸屋根構造梁の 風荷重に関する研究, 日本大学博士学位論文, 1993.12

8) Y. Uematsu, M. Yamada and A. Karasu: Design wind loads for structural frames of flat long-span roofs: gust loading factor for the beams supporting roofs, J. Wind Eng. Ind. Aerodyn., Vol. 66, pp. 35-50, 1997

9) Y. Uematsu, M. Yamada and A. Karasu: Design wind loads for structural frames of flat long-span roofs: gust loading factor for a structurally integrated type, J. Wind Eng. Ind. Aerodyn., Vol. 66, pp. 155-168, 1997

10) Y. Uematsu, M. Yamada: Wind-induced dynamic response and its load estimation for structural frames of circular flat roofs with long spans, Wind \& Structures, Vol. 5, No. 1, pp. 49-60, 2002

11) 立道郁生 : 空間構造の地震応答制御に関する研究, 法政大学博 士学位論文, 2001.3

12) Y. Uematsu, M. Yamada, A. Sasaki: Wind-induced dynamic response and resultant load estimation for a flat long-span roof, J. Wind Eng. Ind. Aerodyn., Vol. 54, pp. 155-166, 1996

13) T. Mori: On the dynamic wind forces on a flat roof, Trans. of A.I.J., No. 206, pp. 9-16, 1973

14) T. Mori: On dynamic response of a flat long-span roof to action of wind, Trans. of A.I.J., No. 241, pp. 91-100, 1976

15) 松本武雄 : 二種類の流れの中の大スパン陸屋根膜面の振動性状 について，第 9 回風工学シンポジウム論文集，pp. 151-156, 1986 [2002年10月15日原稿受理２003年 2 月25日採用決定］ 